\title{
The multicultural experiences, attitudes and efficacy perceptions among prospective teachers
}

\author{
Sıddık Bakır \\ Faculty of Education, Atatürk University, Turkey
}

\begin{tabular}{l}
\hline \hline Article Info \\
\hline Article history: \\
Received Dec 1, 2019 \\
Revised Feb 15, 2020 \\
Accepted Feb 24, 2020 \\
\hline
\end{tabular}

\section{Keywords:}

Multiculturalism

Multicultural education

Teacher capabilities

Prospective teachers

\begin{abstract}
The purpose of this study is to investigate the concepts of multiculturalism and multicultural education and the multicultural experiences, attitudes and efficacies of prospective teachers of Turkish based on different variables. The study was carried out with a total of 249 prospective teachers of which $77 \%$ were female, and $23 \%$ were male who were receiving education in the spring semester of the academic year of 2018-2019 at the department of Turkish education of a state university. The study utilized the Multicultural Efficacy Scale. The data were analyzed by utilizing statistics and statistical techniques such as percentages, frequencies, arithmetic means, standard deviations, t-test and one-way analysis of variance. The Cronbach's Alpha reliability coefficient that was calculated for this study was .868. Based on the findings of the study, it was determined that the prospective Turkish teachers had above-average and positive efficacies towards multicultural education, the saw themselves capable in the "experience, attitude and selfefficacy" dimensions, their perception levels were high, and among different variables, there were significant differences in their multicultural efficacy levels based on the variables of class and place of residence.
\end{abstract}

This is an open access article under the CC BY-SA license.

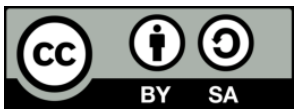

\section{Corresponding Author:}

Siddık Bakır,

Faculty of Education,

Atatürk University,

Atatürk University, Faculty of Education, Turkish Education, 25100, Erzurum, Turkey.

Email: siddik.bakir@atauni.edu.tr

\section{INTRODUCTION}

The prevalence of information and communication technologies has affected and still affecting social, political, economic and cultural life deeply. The changes and developments in question have affected education, and therefore, curricula. In addition to the function of education to train good citizens and labor that is suitable for the social and cultural structure, improvement of individual characteristics has emerged today as an additional important value [1-5]. Nowadays, where the effects of globalization are being felt more with developed technology, serious differences in individual and social structures have also emerged, and interaction has increased very fast by communication becoming easy and economical. This process that is experienced in the sociocultural area has made it inevitable for different cultures to live together, and therefore, brought the concept of multiculturalism forward.

Moreover, establishment of communication or gathering with various cultures by individuals growing up in the information society is shown as a pre-condition for development and acceptance of what is different without reservations. This situation that is shown as a pre-condition is possible by respecting different culture, beliefs, ethnic origins, human rights and differences and developing a positive attitude towards all these differences. The most important way of achieving this is the democratic approaches and 
practices in the education system and institutions. Among the approaches and practices towards making education institutions and curricula more democratic, issues such as human rights, difference, pluralism, multiculturalism, multicultural education and global education hold a significant place [6].

The goal of raising a youth that knows its responsibilities and takes them on, internalizes national and global values and is capable towards teamwork is considered to involve capacities that are prioritized in the changing and transforming function of education systems as a requirement of the age. In this sense, the main objectives of modern education systems include training students who are open to the world, know themselves and have self-esteem, defend equality and have cultural richness, while individuals in societies that achieve this also have characteristics with cultural sensitivity, high motivation, self-respect, self-management, open ideas and capacity of empathy [7-12]. The multidirectional flow of people that is experienced by the reflection of rapid developments in the field of science and technology on social life has made it inevitable for individuals from different socioeconomic and cultural levels to live together [13] and lead schools to embrace a structure where students with different languages, religions, races and cultures gather [14]. This new profile that has emerged at schools has also brought about studies towards teacher capacities that will provide an effective instruction and learning environment for students from different cultures [15]. Several factors such as the past experiences, worldviews and points of view towards change of teachers, who play a significant role in organization of instruction environments based on differences, are effective on organization of multicultural education environments [16]. Therefore, these characteristics that need to be present in teachers that assume significant roles in terms of being able to establish suitable education environments for individuals with different cultural structures in the classroom environment are important in terms of the effectiveness of the multicultural instruction environments to be established, while the experiences, attitudes and efficacy perceptions of teachers and prospective teachers, who are the teachers of the future, also have a significant place. In this sense, investigating the experiences, attitudes and efficacies of teachers and prospective teachers and the transformation processes of these has been a topic of several studies.

The concept of multiculturalism, which was proposed for the first time by Horace Kallen in the 20th century in the adult education literature and rapidly showed development in time Bennett [17], cited in Taştekin et al. [6], may be defined as, “...the process of establishing equal education and learning opportunities to achieve cultural pluralism in the context of democratic values by denying racism and assimilation and showing respect for all types of differences" [16]. According to the American Psychology Association [18], it is defined as awareness of ethnic structure, language, sexual orientation, gender, age, disability status, social class, education, religious orientation and other cultural dimensions and experiencing of these dimensions together. While individuals' experiencing of social class, age, disability status, language, religious origin and cultural differences together is expressed as multiculturalism, the process of equalization of students with these differences and structuring a school environment suitable for this is define as multicultural education [19]. Multicultural education necessitates organization of education environments in a way that is suitable for differences which will allow the student to structure information differently [20]. Thus, multicultural education environments are environments where individual differences are respected, and efforts are carried out to increase not only their awareness levels but also cultural sensitivities [21].

Successful application of these concepts, which are being encountered at all stages and in all programs of the education and instruction process recently, is directly proportional to teacher capacities and awareness. It is also clear that Turkey, which is a significant power in its region and a candidate for membership of the European Union, has a need for educators with the knowledge base and awareness required and work to be conducted on these issues with especially the recent increase in the number of refugees, asylum seekers and foreign students. However, it is expressed that work conducted on this issue not only in Turkey but also in the world is still inadequate [22], and theoretical approaches to the topic are known very little [23]. In recent times, with the proposal of the concepts of multiculturalism and multilingualism in Europe, foreign language teaching connected the foreign language policy of the European Council to two higher objectives. These were: To protect and improve diversity of language and culture as a mutual source of richness, and to make interpersonal relationships, international flow and exchange of thoughts easier [24].

Considering definitions, research and objectives, it may be stated that multicultural education covers improving principles towards social integrity such as respect for differences, equality, justice, empathy, acceptance and compassion, as well as critical thinking skills in education environments, and increasing students' academic success by establishing a link between learning and daily life experiences, and it aims to prepare students in a more equipped way for the future [6].

It is clear that, in Turkey, which has the role of an important bridge between the Western and Eastern cultures with its history and geopolitical position, multicultural education is highly important [25], and thus, multicultural education needs to be adopted at all stages of the education and instruction process. While applying well-conceptualized multicultural curricula that follow each other starting from the preschool

The multicultural experiences, attitudes and efficacy perceptions of prospective teachers ... (Siddik Bakır) 
period is considered as a necessity [26], in the practical sense, developing new policies towards multicultural curricula and internalization of these by students, teachers and administrators are among the needs that are carefully emphasized in Turkey's education system. It is needed to carefully focus on the experiences, attitudes and efficacies of teachers, who play a key role in the education of an individual, regarding multicultural education, and in this context, to allocate more resources for theoretical and experimental studies. Based on this, the purpose of this study is to investigate the experiences, attitudes and efficacies of prospective teachers, who are the teachers, education planners and practitioners of the future, towards multicultural education based on different variables. Especially in relation to investigating the management, attitudes and capacities of educators and prospective educators that work in teaching native and foreign languages towards multiculturalism, conducting such studies and sharing their results have a significant role in stakeholders' acquisition of a more modern identity and design of instruction environments in suitability with this.

\section{RESEARCH METHOD}

\subsection{Research design}

This study was a screening study that was carried out for the purpose of investigating the multicultural experiences, attitudes and efficacy perceptions of prospective teachers of Turkish. A screening model allows the researcher to quantitatively describe the tendencies, attitudes or views within a population through studies conducted on a sample selected from the population [27].

\subsection{Population and sample}

The population of the study consisted of prospective Turkish teachers who were receiving education in the fall semester of the academic year of 2018-2019 at a state university located in the Eastern Anatolia Region of Turkey. The sample consisted of 249 prospective Turkish teachers who were determined by using the simple random sampling method. Information on the demographic characteristics of the sample is provided in Table 1.

Table 1. Information on the demographic characteristics of the sample

\begin{tabular}{|c|c|c|c|}
\hline Variables & Characteristics & $\mathrm{f}$ & $\%$ \\
\hline \multirow[t]{3}{*}{ Gender } & Female & 187 & 75.1 \\
\hline & Male & 62 & 24.9 \\
\hline & Total & 249 & 100.0 \\
\hline \multirow{5}{*}{ Class } & 1st Year & 56 & 22.5 \\
\hline & 2nd Year & 74 & 29.7 \\
\hline & 3rd Year & 71 & 28.5 \\
\hline & 4th Year & 48 & 19.3 \\
\hline & Total & 249 & 100.0 \\
\hline \multirow{5}{*}{ Place of Residence } & Village & 53 & 21.3 \\
\hline & Town & 64 & 25.7 \\
\hline & City & 50 & 20.1 \\
\hline & Metropolitan City & 82 & 32.9 \\
\hline & Total & 249 & 100.0 \\
\hline
\end{tabular}

\subsection{Data collection instruments}

The study utilized the "Multicultural Efficacy Scale" that was developed by Guyton and Wesche [28] and adapted into Turkish by Akcaoğlu and Arsal [29] as the data collection tool. The scale consists of 5 parts. The first part was created for the purpose of comparing the multicultural experiences of participants. The second part consists of items related to the attitudes of participants, and the calculation here is made as 0-8 points for low, 9-13 points for moderate and 14-16 points for high attitudes. The 3rd and 4th parts consist of items regarding self-efficacy perceptions. The calculation for these parts is made as $0-43$ points for low, 44-53 points for moderate and 54-64 points for high self-efficacy. The last part consists of items that aim to determine what participants think about the purpose of multicultural instruction. As in the original scale, the Turkish version of the scale has 3 dimensions. These are the experience $(1,2,3,4,5)$, attitude $(6,7,8,9)$ and self-efficacy $(10,11,12,13,14,15,16,17,18,19,20,21,22,23,24,25)$ dimensions. The item that is the last item of the original scale and measures the points of view of participants regarding multicultural education was kept as it is. The Cronbach's Alpha internal consistency coefficient for the total "Multicultural Efficacy Scale" was calculated as .87, which is accepted as good reliability. The Cronbach's Alpha coefficient for this study was found as .885. 


\subsection{Data analysis}

In data analysis, in cases where comparisons were not possible, descriptive statistics were utilized. Before data analysis, firstly the normal distribution of the data was checked. In cases where the data were normally distributed, independent-samples t-test was used to compare two groups, while one-way analysis of variance (ANOVA) was used to compare more than two groups.

\section{FINDINGS}

Table 2 shows the descriptive statistics that were calculated based on the views of the participants on their multicultural experiences.

Table 2. Views of prospective Turkish teachers on their multicultural experiences

\begin{tabular}{lllll}
\hline Items & Mean & Sd & Interpretation \\
\hline 1) & When I was a child, I played with people who were different than me. & 2.88 & .95 & Sometimes \\
2) & $\begin{array}{l}\text { In my childhood and youth, I went to a school where there were students } \\
\text { different than me. }\end{array}$ & 2.06 & 1.16 & Rarely \\
3) & & 1.00 & Rarely \\
P) $\begin{array}{l}\text { I used to prefer wath differences lived in the neighborhood where I grew up. } \\
\text { differences. }\end{array}$ & 2.42 & .93 & Rarely \\
5) When I was a child/young, I was in the same team and/or club with & 2.26 & 1.04 & Rarely \\
& & & & \\
\hline
\end{tabular}

As seen in Table 2, based on their mean scores, the participants answered as "sometimes" to the statement "When I was a child, I played with people who were different than me", while they answered as "rarely" to the statements "In my childhood and youth, I went to a school where there were students different than me", "People with differences lived in the neighborhood where I grew up", "I used to prefer watching TV shows and films about people with differences" and "When I was a child/young, I was in the same team and/or club with students who had differences". Table 3 shows the descriptive statistics that were calculated based on the multiculturalism attitude and self-efficacy mean scores of the participants.

Table 3. Views of prospective Turkish teachers on their multicultural attitudes and self-efficacies

\begin{tabular}{llll}
\hline Dimensions & Mean & Sd & Interpretation \\
\hline Attitude & 13.59 & 2.31 & Moderate-High \\
Self-Efficacy & 49.77 & 7.29 & Moderate \\
\hline
\end{tabular}

As seen in Table 3, the mean multicultural attitude score of the participants was "moderate-high", while their mean self-efficacy score was "moderate".

The results of the independent-samples t-test that was carried out to determine the differences in the multicultural attitude and self-efficacy scores of the participants based on the variable of gender are shown in Table 4.

Table 4. Independent-samples t-test results on the differences in the multicultural attitude and self-efficacy scores based on the variable of gender

\begin{tabular}{lccccccc}
\hline \multicolumn{1}{c}{ Variable } & Group & $\mathrm{N}$ & $\bar{X}$ & $\mathrm{sd}$ & $\mathrm{df}$ & $t$ & $\mathrm{p}$ \\
\hline \multirow{2}{*}{ Attitude } & Female & 187 & 13.75 & 2.21 & \multirow{2}{*}{247} & \multirow{2}{*}{-1.959} & \multirow{2}{*}{.051} \\
\multirow{2}{*}{ Self-Efficacy } & Male & 62 & 13.09 & 2.52 & & & \\
& Female & 187 & 50.02 & 7.36 & \multirow{2}{*}{247} & -.940 & .348 \\
\hline
\end{tabular}

As seen in Table 4, according to the results of the independent-samples t-test, in terms of the multicultural attitude and self-efficacy mean scores, there was no significant difference between the female students $\left(\bar{X}_{\text {attitude }}=13.75 ; \bar{X}_{\text {self-efficacy }}=50.02\right)$ and the male students $\left(\bar{X}_{\text {attitude }}=13.09 ; \bar{X}_{\text {self-efficacy }}=\right.$ 49.01) $\left(\mathrm{t}_{\text {attitude }(247)}=-1.959, \mathrm{p}>.05 ; \mathrm{t}_{\text {self-efficacy }(247)}=-.940, \mathrm{p}>.05\right)$.

The results of one-way ANOVA that was carried out to determine the differences in the multicultural attitude and self-efficacy scores of the participants based on the variable of class are shown in Table 5 and Table 6.

The multicultural experiences, attitudes and efficacy perceptions of prospective teachers ... (Siddik Bakır) 


\begin{tabular}{lllll}
\multicolumn{4}{c}{ Table 5. Data on descriptive statistics } \\
\hline \multirow{4}{*}{ Attitude } & Variables & $\mathrm{N}$ & $\bar{X}$ & ss \\
& 1st Year & 56 & 14.07 & 1.90 \\
& 2nd Year & 74 & 13.65 & 2.22 \\
& 3rd Year & 71 & 13.49 & 2.32 \\
& 4th Year & 48 & 13.09 & 2.77 \\
\hline \multirow{4}{*}{ Self-Efficacy } & 1st Year & 56 & 51.84 & 6.66 \\
& 2nd Year & 74 & 50.61 & 7.67 \\
& 3rd Year & 71 & 47.92 & 7.12 \\
& 4th Year & 48 & 48.81 & 7.04
\end{tabular}

Table 6. One-way ANOVA results on the differences in the multicultural attitude and self-efficacy scores based on the variable of class

\begin{tabular}{llllllll}
\hline & Multiculturalism & $\begin{array}{l}\text { Sum of } \\
\text { Squares }\end{array}$ & df & $\begin{array}{c}\text { Mean } \\
\text { Squares }\end{array}$ & F & p & $\begin{array}{c}\text { Significant } \\
\text { Difference }\end{array}$ \\
\hline \multirow{4}{*}{ Attitude } & Between groups & 25.976 & 3 & 8.659 & & & \\
& Within Group & 1294.502 & 245 & 5.284 & 1.639 & .181 & \\
& Total & 1320.479 & 248 & & & & \\
\multirow{5}{*}{ Self-Efficacy } & Between groups & 580.573 & 3 & 193.524 & & & $1>3$ \\
& Within Group & 12614.429 & 245 & 51.487 & 3.759 & $\mathbf{. 0 1 1}$ & \\
& Total & 13195.002 & 248 & & & & \\
\hline
\end{tabular}

A one-way ANOVA test was carried out to determine whether or not there was a difference in the multicultural attitude and self-efficacy scores of the participants based on their class, and while there was no significant difference among the groups based on their attitude mean scores $\left(\mathrm{F}_{(3-245)}=1.639, \mathrm{p}>0.05\right)$, there was a significant difference based on their self-efficacy mean scores $\left(\mathrm{F}_{(3-245)}=3.759, \mathrm{p}<0.05\right)$. As a result of the multiple comparisons test that was carried out, it was seen that the significant difference in the multicultural self-efficacy dimension was between the 1st-year prospective teachers $(\bar{X}=51.84)$ and the 3rd-year prospective teachers $(\bar{X}=47.92)$ and in favor of the 1 st-year participants. The effect size value that corresponds to the ratio of variance in the dependent variable explained by the independent variable was found as $\eta^{2}=.044$, and this showed that the variable of class had a moderate-level effect on the mean scores of multicultural self-efficacy.

The results of one-way ANOVA that was carried out to determine the differences in the multicultural attitude and self-efficacy scores of the participants based on the variable of place of residence are shown in Tables 7 and 8.

A one-way ANOVA test was carried out to determine whether or not there was a difference in the multicultural attitude and self-efficacy scores of the participants based on their place of residence, and while there was no significant difference in the mean scores of the groups for the attitude dimension $\left(\mathrm{F}_{(3-245)}\right.$ $=1.286, \mathrm{p}>0.05)$, there was a significant difference in the self-efficacy dimension $\left(\mathrm{F}_{(3-245)}=2.724, \mathrm{p}<0.05\right)$. As a result of the multiple comparisons test that was carried out, it was seen that the difference in the selfefficacy dimension was between the prospective teachers living in metropolitan cities $(\bar{X}=51.03)$ and those living in villages $(\bar{X}=47.63)$ and in favor of the participants living in metropolitan cities. The effect size value that corresponds to the ratio of variance in the dependent variable explained by the independent variable was found as $\eta 2=.032$, and this showed that the variable of place of residence had a moderate-level effect on the mean scores of multicultural self-efficacy.

Table 7. Data on descriptive statistics

\begin{tabular}{llccc}
\hline Multiculturalism & Variables & $\mathrm{N}$ & $\bar{X}$ & ss \\
\hline \multirow{4}{*}{ Attitude } & Village & 53 & 13.45 & 2.37 \\
& Town & 64 & 14.02 & 2.18 \\
& City & 50 & 13.20 & 2.51 \\
& Metropolitan City & 82 & 13.59 & 2.23 \\
\hline \multirow{4}{*}{ Self-Efficacy } & Village & 53 & 47.63 & 6.69 \\
& Town & 64 & 50.47 & 7.99 \\
& City & 50 & 49.09 & 7.05 \\
& Metropolitan City & 82 & 51.03 & 7.01 \\
\hline
\end{tabular}


Table 8. One-way ANOVA results on the differences in the multicultural attitude and self-efficacy scores based on the variable of place of residence

\begin{tabular}{|c|c|c|c|c|c|c|c|}
\hline Multiculturalis & & Sum of Squares & $\mathrm{df}$ & Mean Squares & $\mathrm{F}$ & $\mathrm{p}$ & Significant Difference \\
\hline \multirow{4}{*}{ Attitude } & Between & 20.196 & 3 & 6.732 & \multirow{4}{*}{1.286} & \multirow{4}{*}{.286} & \\
\hline & groups & & & & & & \\
\hline & Within Group & 1300.283 & 245 & 5.307 & & & \\
\hline & Total & 1320.479 & 248 & & & & \\
\hline \multirow{4}{*}{ Self-Efficacy } & Between & 425.894 & 3 & 141.965 & \multirow{4}{*}{2.724} & \multirow{4}{*}{.045} & \multirow{4}{*}{$\begin{array}{l}\text { Metropolitan } \\
\text { City>Village }\end{array}$} \\
\hline & groups & & & & & & \\
\hline & Within Group & 12769.108 & 245 & 52.119 & & & \\
\hline & Total & 13195.002 & 248 & & & & \\
\hline
\end{tabular}

\section{RESULTS AND DISCUSSION}

Today, where societies are experiencing a very fast change and transformation in the social and cultural sense, it is not possible to consider education separately from this process. In today's world that is getting increasingly smaller where borders are being eliminated and transitivity increases, while people's interests in and tendencies towards education, science and communication increase, their rates of knowing different cultures, living together with them and interacting with them have also started to rise fast. This situation has naturally made it inevitable for educators to reorganize in this direction and form and implement new education environments and programs suitable for it.

With the differences diversifying in increasingly growing countries, the world is getting smaller, but different cultures and identities gather at the point of multiculturalism for living together. At this point, multiculturalism is considered as an alternative way to prevent conflicts between differences [30]. It is an indisputable fact that this alternative way naturally affects the education approaches and policies of countries, and there is a higher need to relate new concepts such as multilingualism, multiculturalism and digital nativism to the field of education and conduct studies in this direction. Considering the near future where educators and students who will work in the field of education in the future will interact more with students from several ethnic groups with different numbers and qualities, it is believed that studies on attitudes, perceptions and capacities on this issue have great importance in this context.

According to the results on this study which was carried out on the multicultural attitudes and selfefficacy perceptions of prospective teachers of Turkish, the participants generally had high and positive multicultural experience, attitude and efficacy perceptions. Considering the literature, this result was supportive of the findings of the studies [31-35]. Based on the studies of the researchers conducted with students, teachers, administrators and prospective teachers, it is possible to reach the conclusion that the participants valued multiculturalism, and they had a positive attitude towards multicultural education.

In this study where the multicultural attitudes and efficacies of prospective Turkish teachers were examined, it was determined that there was no significant difference in the participants' multicultural attitude and self-efficacy mean scores based on their gender. This result was in agreement with the results of the study by Yazic1 et al. [34] conducted with 415 teachers of different branches employed at the province of Tokat and its districts, the study by Polat [32] conducted with 203 school principals appointed for the first time to public schools in the province of Kocaeli and the study by Özdemir and Dil [33] conducted with 204 teachers working in the province of Çankırı. However, in the literature, there are also studies which determined that the variable of gender created a significant difference on the mean scores of multiculturalism and multicultural education, as opposed to the result mentioned above. In the study conducted by Coşkun [36] to determine and compare the attitudes of students of the department of Religious Culture and Moral Knowledge (DKAB) at the Faculty of Theology and Faculty of Education towards multicultural education, female students were found to have higher scores, while in the study by Demir and Başarır [37], in the study by Demircioğlu and Özdemir [38] on 156 students receiving pedagogic formation training at Çankırı Karatekin University and the studies of Tortop [39], Engin and Genç [40], Şahin and Kılınç [41], Arslan and Çalmaşur [42] and Güngör et al. [35], it was seen that there was a difference based on the variable of gender in favor of women, and the attitudes of women towards multicultural education were significantly higher than those of men.

Looking at the variable of class based on the findings of the study, it is seen that there was a significant difference in the multicultural self-efficacy mean scores based on the variable of class in favor of the participants attending their 1st year. In the study by Coşkun [36], which included only 4th-year students with the assumption that targeted outcomes to be obtained in the context of multiculturalism would reach the maximum level on the level of the 4th year, it was seen that the attitudes of the participants towards multicultural education were positive, while the levels of attitudes did not significantly vary based on the variables of gender, economic level, mother's/father's education levels, ÖSS-AGNO scores, type of the educational institution and place of residence. According to the data obtained as a result of the study by

The multicultural experiences, attitudes and efficacy perceptions of prospective teachers ... (Siddik Bakır) 
Y1lmaz and Gökçen [43] with 404 prospective form teachers on intercultural sensitivity, while the variable of gender did not lead to a difference in attitudes, the sensitivity levels of 3rd- and 4th-year students were higher than those of 1st- and 2nd-year students. In the study by Şahin and Kılınç [41] that was conducted to determine the views of prospective teachers on their multicultural personality levels, there were significant differences in the cultural empathy sub-dimension based on the variable of class in favor of 1st-year students as in the case of this study. While Güngör et al. [35] determined that prospective teachers have high levels of positive attitudes towards multiculturalism, their multiculturalism attitudes did not vary significantly based on their ages or years of study, but there were significant differences in their attitudes based on gender, region of origin, program and native languages.

Looking at the last variable of the study, place of residence, based on the findings, while there was no significant difference in the mean attitude scores based on the variable, there was a significant difference in the mean self-efficacy scores, and the significant difference was between those living in metropolitan cities and those living in villages in favor of the former. While this result supported the studies of Yazic1 et al. [34], Bulut and Başbay [44], Koçak and Özdemir [15] and Arslan and Çalmaşur [42] with teachers and prospective teachers on multicultural education and democratic attitudes, it contradicted the finding of Coşkun [36] in their study with university students that results of the students did not significantly differ based on the qualities of the place of their experiences.

Based on the results, the following recommendations may be offered for future studies: This study is limited with the views of a certain group of students from Atatürk University. This is why the findings of the study are limited. Conducting the study with more university students, teachers and also instructors will enrich the literature as it will provide more generalizable findings. It will also provide the opportunity of comparing universities, faculties and departments in terms of their multicultural education programs, if any.

In addition to experimental and qualitative studies on experiences, attitudes and efficacy perceptions towards multicultural education, usage of different data collection instruments and different variables will contribute greatly to the literature. As in the case of prospective teachers, the same scale may be applied with teachers and instructors of Turkish who work at provinces where students of foreign nationality are found prevalently, and a comparative study may be carried out in terms of their experiences, attitudes and efficacy perceptions and those of their colleagues working in different provinces. Different scales on this topic may be applied on the same population and/or sample with different research designs, and the results may be compared. Furthermore, whether or not there is a relationship between the awareness levels of teachers and prospective teachers of Turkish and their experiences, attitudes and efficacies may be measured.

Moreover, based on the necessity to provide multicultural awareness knowledge and skills, investigating the reasons for not having provided these, provision of in-service or pre-service trainings for teachers and planning projects, workshops and other practices for prospective teachers that would increase their knowledge, skill and awareness levels in the instruction process will be useful. In today's world where multicultural education and awareness on it are a factor that needs to be considered starting from primary education through people's professional lives, it is an indispensable reality that more in-depth studies need to be conducted on this issue. In this sense, considering that experiences, attitudes and efficacy perceptions towards multiculturalism are affected by different variables, it is seen to be important to replicate such a study with variables such as status of having studied or lived abroad, knowing a foreign language and having received education on different cultures, as it will contribute to the field.

\section{CONCLUSION}

Based on the findings on the multicultural experiences of the prospective Turkish teachers, it was seen that they did not have much experience. The participants answered as "sometimes" to the statement "When I was a child, I played with people who were different than me", while they answered as "rarely" to the statements "In my childhood and youth, I went to a school where there were students different than me", "People with differences lived in the neighborhood where I grew up", "I used to prefer watching TV shows and films about people with differences" and "When I was a child/young, I was in the same team and/or club with students who had differences."

According to the results on this study which was carried out on the multicultural attitudes and selfefficacy perceptions of prospective teachers of Turkish, the participants generally had high and positive multicultural experience, attitude and efficacy perceptions. 


\section{REFERENCES}

[1] Gürol, M. "Eğitim teknolojisinde yeni paradigma: oluşturmacılık," Firat Üniversitesi Sosyal Bilimler Dergisi, vol. 12, no. 1, pp. 159-183, 2002.

[2] Özden, Y., \& Şimşek, H. "Davranışçılıktan oluşturmacıllğa: Öğrenme paradigmasının dönüşümü ve Türk eğitimi," Bilgi ve Toplum Dergisi, vol. 1, pp. 71-82, 1998.

[3] Tezci, E. “Türkiye'de ilköğretim politikaları,” (Ed. Gümüş, A.), Türkiye’de Eğitim Politikalarl. Ankara: Nobel Akademi, 2015.

[4] Uysal, A., \& Tezci, E. "Küreselleşen dünyada eğitimin yeni önceliği: Düşünmeyi öğrenme,” Doğu Anadolu Bölgesi Araştırmaları Dergisi, vol. 2, no. 3, pp. 167-173, 2004.

[5] Yıldırım, S. "Kosova'daki öğretmenlerin çok kültürlü eğitime yönelik bilgi, inanç, tutum ve öz yeterliklerinin sınıf içi uygulamalarıyla ilişkisinin incelenmesi," (Yayımlanmamış doktora tezi), Balıkesir Üniversitesi, Balıkesir, 2016.

[6] Taştekin, E., Bozkurt Yükçü, Ş., İzoğlu, A., Güngör, İ., Iş̧k Uslu, A., \& Demircioğlu, H. "Okul öncesi öğretmenlerinin çok kültürlü eğitime yönelik tutumlarının ve algılarının incelenmesi," Hacettepe Journal of Educational Research, vol. 2, no. 1, pp. 1-20, 2016.

[7] Balay, R. "Küreselleşme, bilgi toplumu ve eğitim," Ankara Üniversitesi Eğitim Bilimleri Fakültesi Dergisi, vol. 37, no. 2, pp. 61-82, 2004.

[8] Chen, G., \& Starosta, W. J. "The development and validation of the intercultural sensitivity scale," Paper presented at the Annual Meeting of the National Communication Association. Seattle, WA. 2000.

[9] Onur Sezer, G., \& Bağçeli Kahraman, P. "Öğretmen adaylarının çok kültürlü eğitime yönelik tutumları ile kültürlerarası duyarlılıkları,” Mersin Üniversitesi Eğitim Fakültesi Dergisi, vol. 13, no. 2, pp. 550-560, 2017.

[10] Üstün, E. "Öğretmen adaylarının kültürlerarası duyarlılık ve etnik merkezcilik düzeylerin etkileyen etmenler," (Yayımlanmamıs yüksek lisans tezi), Yıldız Teknik Üniversitesi, İstanbul, 2011.

[11] Polat, İ. \& K1lı̧, E. “Türkiye'de çok kültürlü eğitim ve çok kültürlü eğitimde öğretmen yeterlilikleri,” YYÜ Eğitim Fakültesi Dergisi, vol. 10, no. 1. pp. 352-372, 2013.

[12] Yaşar Ekici, F. "Okul öncesi öğretmen adaylarının kültürel zekâ düzeyleri ve çok kültürlü eğitime yönelik tutumları," Kastamonu Ĕgitim Dergisi, vol. 25, no. 5, pp. 1941-1956, 2017.

[13] İlbuğa, E. U. "Çok kültürlülük, ulus ötesilik ve kültürlerarası iletişim yeterliliği," Çankaya University Journal of Humanities and Social Sciences, vol. 7, no. 1, pp. 163-180, 2010.

[14] Ambe, E. B. "Fostering multicultural appreciation in pre-service teachers through multicultural curricular transformation," Teaching and Teacher Education, vol. 22, pp. 690-699, 2006.

[15] Koçak, S., \& Özdemir, M. “Öğretmen adaylarının çok kültürlü eğitime yönelik tutumlarında kültürel zekânın rolü,” Illkögretim Online, vol. 14, no. 4, pp. 1352-1369, 2015.

[16] Kaya, İ., \& Aydın, H. “Çoğulculuk Çok kültürlü ve Çok dilli Eğitim,” Ankara: Anı Yayıncılık. 2014.

[17] Bennett, C. "Genres of research in multicultural education," Review of Educational Research, vol. 71, no. 2, pp. 171-217, 2001.

[18] American Psychological Association (APA). "Multicultural guidelines: an ecological approach to context, identity, and intersectionality," http://www.apa.org/about/policy/multicultural-guidelines.pdf 2017.

[19] Cırık, İ. "Çok kültürlü eğitim ve yansımaları," Hacettepe Eğitim Fakültesi Dergisi, vol. 34, pp. 27-40. 2008.

[20] Türkan, A., Aydın, H., \& Üner, S. S. "Öğretmen adaylarının çok kültürlü eğitime yönelik tutumları ile epistemolojik inançları arasındaki ilişkinin incelenmesi," Illköğretim Online, vol. 15, no. 1, pp. 48-159, 2016.

[21] Mahiroğulları, A. "Küreselleşmenin kültürel değerler üzerine etkisi," Sosyal Siyaset Konferansları Dergisi, vol. 50, pp. 1275-1288, 2005.

[22] Başbay, A. \& Kağnıc1, D. Y. “Çok kültürlü yeterlik algıları ölçeği: Bir ölçek geliştirme çalıșması,” Eğitim ve Bilim, vol. 36, no. 161, pp. 199-212, 2011.

[23] Açıkalın, M. "Sosyal bilgiler eğitiminde yeni yaklaşımlar: Çok kültürlü ve küresel eğitim," İlkögrretim Online, vol. 9, no. 3, pp. 1226-1237, 2010.

[24] Polat, T. "Avrupalılık Bağlamında Kültür Boyutuyla Yabancı Dil," Alman Dili ve Edebiyatı Dergisi, pp. 29-39, 2001.

[25] Aydın, H. "Dünyada ve Türkiye'de çok kültürlü eğitim tartışmaları ve uygulamaları,” Ankara: Nobel Yayınlar1. 2013.

[26] Banks, J. A. "Multicultural education: Historical development, dimensions, and practice," Review of Research in Education, pp. 3-49, 1993.

[27] Creswell, J. W. "Research design: qualitative, quantitative and mixed methods approaches," (4th edt.). London: SAGE Publications. 2013.

[28] Guyton, E. M., \& Wesche, M. V. "The multicultural efficacy scale: Development, item selection, and reliability," Multicultural Perspectives, vol. 7, no. 4, pp. 21-29, 2005.

[29] Akcaoğlu, M. Ö., \& Arsal, Z. "Çok kültürlü Yeterlik Ölçeğinin Türkçe’ye Uyarlanması: Geçerlik ve Güvenirlik Çalışması," Kastamonu Üniversitesi Kastamonu Ĕgitim Dergisi, vol. 26, no. 1, pp. 261-270, 2018.

[30] Yakışır, A. N. "Modern bir olgu olarak çok kültürlülük," (Yayımlanmamış yüksek lisans tezi), Selçuk Üniversitesi, Konya, 2009.

[31] Renko, Y. K., \& Yoder, J. H. "Education for international understanding: A comparison for attitudes and selfperceived skills of teacher education students in Finland and California," Presented in annual conference of the comparative education society of Europe. 28 June, Copenhagen, 1994.

[32] Polat, S. "Okul müdürlerinin çok kültürlülüğe ilişkin tutumları," Hacettepe Üniversitesi Eğitim Fakültesi Dergisi, vol. 44, pp. 334-343, 2012. 
[33] Özdemir, M., \& Dil, K. “Öğretmenlerin çok kültürlü eğitime yönelik tutumları: Çankırı ili örneği,” Ankara Üniversitesi Ĕ̈itim Bilimleri Fakültesi Dergisi, vol. 46, no. 2, pp. 215-232, 2013.

[34] Yazıcı, S., Başol, G., \& Toprak, G. "Öğretmenlerin çok kültürlü eğitim tutumları: bir güvenirlik ve geçerlik çalışması,” Hacettepe Üniversitesi Ĕ̈itim Fakültesi Dergisi, vol. 37, pp. 229-242, 2009.

[35] Güngör, S., Buyruk, H., \& Özdemir, Y. "Öğretmen adaylarının çok kültürlülüğe ilişkin tutumları,” Elektronik Sosyal Bilimler Dergisi, vol. 17, no. 66, pp. 816-837, 2018.

[36] Coşkun, M. K. "Din kültürü ve ahlak bilgisi öğretmen adaylarının çok kültürlü eğitime yönelik tutumları (İlahiyatEğitim DKAB karşılaştırmas1)," Atatürk Üniversitesi Sosyal Bilimler Enstitüsü Dergisi, vol. 17, no. 1, pp. 33-44, 2012.

[37] Demir, S., \& Başarır, F. "Evaluation of preservice teachers' opinions of multicultural education,” IIB International Refereed Academic Social Sciences Journal, vol. 4, no. 9, pp. 1-30, 2013.

[38] Demircioğlu, E., \& Özdemir, M. "Pedagojik formasyon öğrencilerinin çok kültürlü eğitime yönelik tutumlarının bazı değişkenlere göre incelenmesi," Ege Eğitim Dergisi, vol. 15, no. 1, pp. 211-232, 2014.

[39] Tortop, H. S. "Öğretmen adaylarının üstün yetenekli ve çok kültürlü eğitime ilişkin tutumları," Üstün Yetenekliler Ë̆itimi ve Araştırmaları Dergisi (UYAD), vol. 2, no. 2, pp. 16-26, 2014.

[40] Engin, G., \& Genç, S. Z. "Attitudes teacher candidates towards multicultural education (Çanakkale Onsekiz Mart University Example)," Route Educational and Social Science Journal, vol. 2, no. 2, pp. 30-39, 2015.

[41] Şahin, M. H., \& Kilınç, E. "Eğitim Fakültesi öğrencilerinin çok kültürlü kişilik düzeylerinin belirlenmesi," Eğitim ve Öğretim Araştırmaları Dergisi (JRET), vol. 5, no. 1, pp. 126-136, 2016.

[42] Arslan, A., \& Çalmaşur, H. "İlkokul ve ortaokul öğretmenlerinin çok kültürlü eğitim tutumları ve demokratik tutumlarının çeşitli değişkenler açısından incelenmesi," Atatürk Üniversitesi Kazım Karabekir Eğitim Fakültesi Dergisi, vol. 34, pp. 90-109, 2017.

[43] Yılmaz, F., \& Göçen, S. "Sınıf öğretmeni adaylarının kültürlerarası duyarlılık hakkındaki görüşlerinin farklı değişkenlere göre incelenmesi," Adlyaman Üniversitesi Sosyal Bilimler Enstitüsü Dergisi, vol. 15, pp. 373-392, 2013.

[44] Bulut, C., \& Başbay, A. "Öğretmenlerin çok kültürlü yeterlik algılarının incelenmesi,” K. Ü. Kastamonu Eğitim Dergisi, vol. 23, no. 3, pp. 957-978, 2014. 